\title{
A Focus on Motor Competence as Alternative Strategy for Weight Management
}

\section{Clemens Drenowatz}

Educational College Vorarlberg, Division of Physical Education, Liechtensteinerstrasse 33-37, 6800 Feldkirch, Austria

Correspondence to:

Clemens Drenowatz

Educational College Vorarlberg

Division of Physical Education

Liechtensteinerstrasse 33-37

6800 Feldkirch, Austria

Tel: +43 (9)5522 31199-115

E-mail: clemens.drenowatz@ph-vorarlberg.ac.at

Received: May 30, 2017

Accepted: July 07, 2017

Published: July 12, 2017

Citation: Drenowatz C. 2017. A Focus on Motor Competence as Alternative Strategy for Weight Management. J Obes Chronic Dis 1(2): 31-38.

Copyright: (C) 2017 Drenowatz C. This is an Open Access article distributed under the terms of the Creative Commons Attribution 4.0 International License (CC-BY) (http://creativecommons.org/ licenses/by/4.0/) which permits commercial use, including reproduction, adaptation, and distribution of the article provided the original author and source are credited.

Published by United Scientific Group

\begin{abstract}
The high prevalence of overweight and obesity has been identified as major threat to future public health. Excess body weight not only impairs individual quality of life but is also associated with considerable costs. The fact that obesity rates have been rising throughout the world despite considerable efforts suggests that alternative strategies for addressing this problem are warranted. One such strategy may be a stronger emphasis on the development of motor competence. This narrative review provides an overview of the major theoretical models describing the longitudinal associations of motor competence, physical activity and body weight along with empirical evidence supporting the potential contribution of motor competence in obesity prevention. It also gives some practical guidance for the implementation of interventions emphasizing the development of motor competence. Despite the fact that childhood and adolescence appear to be of particular importance for ensuring a high motor competence, it should be considered that even adults could benefit from increased motor competence. Well-developed motor competence is associated with higher motivation for participation in various forms of physical activity, and, therefore, facilitates an active lifestyle throughout adulthood. Taken together, it appears that emphasizing the development of motor competence at young ages provides a viable option for the sustainable promotion of physical activity, which is a crucial component in long-term weight management.
\end{abstract}

\section{Keywords}

Motor skills, Motor abilities, Functional movement skill, Obesity, Overweight

\section{Introduction}

Excess body weight has been identified as major health problem due the association with cardiovascular and metabolic disease, orthopedic problems, poor pulmonary function, depressive symptoms and overall quality of life [13]. With more than 2 billion people or roughly $30 \%$ of the world population being considered overweight or obese [4], these problems not only affect the individual but also put a significant burden on health care systems. Excess body weight has been associated with increased doctor's visits, hospital stays as well as decreased productivity [5,6]. Accordingly, obesity has been shown to increase both inpatient and outpatient spending by $36 \%$ along with a $77 \%$ increase in costs for medications [7]. Overall, it has been estimated that $10 \%$ of all healthcare expenditures can be attributed to weight-related health issues [8]. Of particular concern is the increasing prevalence of overweight and obesity during childhood $[9,10]$, which increases the risk for metabolic problems already at young ages [11]. Further, excess body weight increases the risk for adult obesity [12]. Even in the absence of adult obesity, however, children with excess body weight have 
an increased risk for chronic disease and premature death [13]. Accordingly, the prevention of childhood overweight and obesity has been declared one of the largest challenges of the $21^{\text {st }}$ century [14].

\section{Limited Success of Current Intervention Strategies}

Despite considerable efforts in addressing this obesity epidemic current strategies targeting weight loss and weight management have been of limited success [15]. In fact, the average body weight of children in the United States has increased by $5 \mathrm{~kg}$ during the last 3 decades [16]. Given the large number of intervention strategies in various settings, including schools and communities, this development indicates that our understanding of the complex interaction of key contributors to excess body weight remains limited. While biological and genetic factors need to be considered in the regulation of body weight, behavioral adjustments appear to be of particular importance due to the large shift in population weight in a relatively short period of time. Specifically, poor dietary choices and low physical activity (PA) have been suggested as key contributors to excess body weight $[17,18]$. Even though these correlates of energy balance appear to be the obvious choice for behavioral interventions, not all current recommendations have been backed by scientific data. Data on the association between high-fat foods and sugar-sweetened beverages with overweight and obesity have been inconsistent [19-21]. Nevertheless, dietary intake should be considered an important contributor to a healthy lifestyle. Rather than demonizing specific foods, a balanced diet and regular meal pattern in children, however, should be emphasized in order to establish healthy dietary choices in the long-term [22, 23].

Along with changes in the food environment there has been a decline in physical demands of daily living [24, 25]. In youth these changes have promoted indoor activities and high media utilization [26], which resulted in a majority of youth not meeting current PA recommendations of 60 minutes of moderate to vigorous PA [27-29]. Given the well documented benefits of PA on weight management, cardiovascular, metabolic and skeletal health as well as psychological well-being [30-32] insufficient PA is considered another major health risk factor in youth [33]. As has been shown for obesity interventions, efforts to achieve sustainable increases in PA, however, have been of limited success [34]. In light of these data, it may be time to consider alternative approaches for the promotion of an active lifestyle that facilitates long-term weight management. Previous research indicates that low motor competence may have contributed to the high prevalence of obesity in youth [35-38]. In addressing the benefits of motor competence and its association with PA and body weight this narrative review emphasizes the development of motor competence as a potential strategy for a sustainable promotion of an active lifestyle, which is crucial in long-term weight management.

\section{Motor Competence: Terminology and Trends}

Motor competence reflects a person's ability to execute different motor tasks, including the coordination of fine and gross motor skills necessary to manage everyday tasks $[39,40]$. It has recently been suggested to use motor competence as global term, which incorporates previously used terminologies such as motor proficiency, motor performance, motor ability, motor coordination, motor skills or fundamental movement skills [33]. Accordingly, motor competence forms the foundation for specialized skills that are required for successful participation in popular sports and active leisure activities, including locomotion and object control [41, 42]. Locomotor skills are defined as movements that propel the body through space (e.g., running, jumping, skipping, hopping) while object control relates to movements used in manipulating objects (e.g., throwing, kicking, catching) [43]. The development of motor competence is a critical determinant of children's general development as it influences physical, psychological and mental health along with overall well-being [33, 44-49].

As has been shown for PA, available data on motor competence in youth indicate a decline $[50,51]$ resulting in low motor competence in children and adolescents $[52,53]$. The limited success of current PA and weight loss interventions has, at least in part, been attributed to the lack of attention towards the development of motor competence, particularly in children with excess body weight [54]. Accordingly, it has been argued that weight loss intervention strategies in children should initially address deficiencies in motor competence in order to allow children to successfully participate in healthenhancing PA $[55,56]$. As higher motor competence has been associated with increased motivation and enjoyment of being physically active [56-58], children with high motor competence have shown a less pronounced decline in PA as they progress through childhood and into adolescence [57,59]. Accordingly, high motor competence during childhood has been associated with higher levels of moderate-to-vigorous $\mathrm{PA}$ in adults even though there was no difference in participation in organized sports [60]. These results emphasize the potential of focusing on the development of motor competence for the facilitation of a sustainable participation in various physical activities beyond the intervention period.

Even though rudimentary movement patterns develop naturally during childhood, the development of motor competence needs to be nurtured and is influenced by biological, psychological, social, cognitive and motivational factors [61]. Accordingly, appropriate instruction, practice, encouragement and feedback are necessary for the optimal development of motor competence [42, 62, 63]. Children need to be provided with opportunities to engage in a variety of movements including supervised exercise as well as free play $[64,65]$. Free play has been shown to facilitate learning, particularly in younger children and it may provide opportunities for the development of additional movement skills in different contexts [66]. Further, play often induces movements associated with moderate-to-vigorous intensity [59]. Structured activities that emphasize various forms of locomotion and object control skills, nevertheless, could provide additional benefits. Accordingly, school and community programs that focus on developmentally appropriate movement experiences have been shown to 
improve motor competence in children and adolescents [63, 67-69]. Given that motor competence has been considered a sustainable outcome, it could induce relatively permanent change of an individual's behavioral capability along with changes in behavioral preferences including higher physical activity levels $[57,70,71]$.

\section{Longitudinal Associations and Theoretical Models of the Development of Motor Competence}

In order to consider the development of motor competence as a viable intervention targeting increased PA and a healthy body weight it should, however, be clarified whether increased motor competence increases subsequent participation in PA or whether it is the result of increased engagement in PA [72]. Most likely there exists a reciprocal, synergistic relationship between motor competence, PA and body weight [73-76]. Nevertheless, it has been suggested that directionality and strength of the developmentally dynamic relationship between motor competence and PA varies from infancy throughout childhood and into adolescence [76]. Particularly middle childhood has been proposed as a critical time, where either positive or negative trajectories of motor competence, PA, and body weight begin to diverge [33] (Figure 1). Two theoretical models have addressed the longitudinal association between the development of motor competence and PA along with the implications for weight progression - the dynamic association model [76] and the hierarchical model [77].

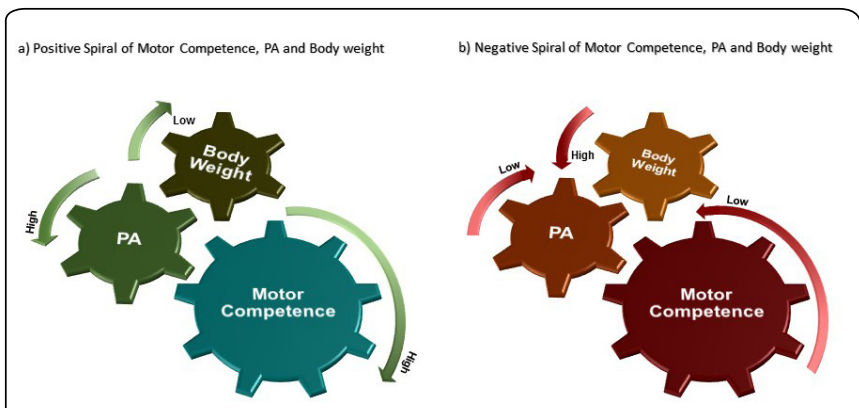

Figure 1: Interaction of motor competence, physical activity (PA) and body weight.

The dynamic association model emphasizes the reciprocal relationship between $\mathrm{PA}$, actual and perceived motor competence with variations in strength and directionality between these components [76]. It also acknowledges that the relationship between PA and motor competence is low during early childhood due to environmental and parental influences on these parameters as well as limited prior experience with structured movement programs. Initially, PA appears to be necessary in order to develop unspecific motor skills or motor milestones at young ages $[78,79]$. The need of PA to develop rudimentary motor skills may also be indicated by an infant's drive to move. As children with higher PA will enhance their motor competence this association strengthens during the transition into middle and late childhood but also starts to shift in directionality. As children start to compare their motor competence to peers their perceived or actual motor competence may become the primary determinant of PA participation. During the transition into adolescence the association continues to strengthen with reverse directionality. Those with enhanced actual and perceived motor competence will be more motivated to participate in different forms of PA, which further contributes to the development of motor competence $[78,79]$. Accordingly, motor competence has been suggested as a primary determinant for participation in PA and exercise during adolescence and into adulthood, particularly in activities consisting of moderate and vigorous PA [64, 76, 80]. This is also in line with the competence motivation theory [81], which suggests that motivation to engage in various activities such as PA is influenced by competence and enjoyment of the respective activity. Low motor competence, on the other hand, may result in less pleasant experiences with various movement activities, which would increase the risk for low PA. Further, it has been shown that low motor competence reduces the motivation to engage in more challenging activities [78, 82], which impairs the refinement of motor skills and contributes to a vicious cycle of low motor competence and low PA. This reinforcing association between PA and motor competence will also affect weight status over time. Accordingly, longitudinal data showed a positive trajectory for healthy weight and increased motor competence, while low motor competence was associated with increased risk for overweight and obesity [57, 59, 73, 83-85].

The hierarchical model puts an even stronger emphasis on motor competence as prerequisite for engagement in PA. As a result of growth, maturation and experience children progress through four levels of motor competence consisting of reflexes, fundamental motor skills, transitional motor skills, and sport specific skills [77]. Of particular importance are so-called proficiency barriers as these most likely affect motivation for a sustainable engagement in various forms of PA and sports. Children, whose motor competence exceeds the proficiency barrier are more likely to maintain higher PA levels throughout the lifespan while those who do not break through the proficiency barrier are less likely to continue their engagement in PA. Accordingly, Lopes et al. showed an attenuation of the age-related decline in elementary school children with higher motor competence while low motor competence augmented the decline in PA [59]. Specifically, object control skills have been shown to affect PA participation $[57,86]$, which may be attributed to their importance in many popular sports. Another explanation could be that object control skills require specific environmental stimuli, including learning opportunities with feedback and instructions, that are influenced by socio-economic factors, which are associated with PA as well. Limited movement experience and low motor competence would also make it more difficult to motivate adults for participation in various forms of PA at later stages in their lives and, therefore, hinder traditional PA programs.

Besides the association between motor competence and PA there is evidence that motor competence affects change in adiposity independent of PA during elementary school years [58]. Body weight, however, also influences the development of motor competence. Previous research showed a slower development of motor competence in overweight/ 
obese children compared to their normal weight peers [87, 88]. Weight loss, on the other hand, has been associated with a more pronounced development of motor competence. The development of object control skills, however, has been shown to be less affected by body weight [80] and, therefore, a focus on motor competence may still be a viable option when targeting excess weight gain.

\section{Practical Implications}

Interventions targeting an improvement in motor competence have been shown to be effective in children $[63,68,89]$. In addition, motor competence appears to be a sustainable outcome in children and adolescents and has important implications for lifespan PA and body weight [49, $90,91]$. Given the fact that health promotion should target sustainable behavior change or facilitate the maintenance of healthy behaviors (i.e. sufficient PA), targeting motor competence should be considered as viable strategy in the promotion of an active lifestyle that facilitates long-term weight management. Despite low correlations between motor competence and health related outcomes (e.g., PA, body weight) during early childhood, it has been argued that motor competence provides the foundation for an active lifestyle [42, 76]. The necessity to specifically nurture the development of motor competence in young ages, however, is often overlooked. During early childhood, a focus should be on a wide variety of movement experiences in order to provide the foundation for future development. As elementary-school years have been suggested as the optimal time for the development of motor competence $[42,92]$, this age group should be provided with a range of tasks that promote the development of various broad movement skills. An overview of key characteristics for the selection of movement experiences targeting the promotion of motor competence is provided in Table 1.

Table 1: Key characteristics of movement experiences for the promotion of
motor competence (based on Kosel A. [108])
\begin{tabular}{|l|l|}
\hline $\begin{array}{l}\text { Self-determined } \\
\text { Difficulty }\end{array}$ & $\begin{array}{l}\text { Children determine the difficulty of the task } \\
\text { based on their experience and learn to evaluate } \\
\text { their current abilities }\end{array}$ \\
\hline $\begin{array}{l}\text { Self-selected } \\
\text { Activities }\end{array}$ & $\begin{array}{l}\text { Children participate in and potentially develop } \\
\text { movement tasks under guidance (f.ex. balance } \\
\text { beam can be crossed in various ways, which is } \\
\text { determined by the student) }\end{array}$ \\
\hline High Engagement & $\begin{array}{l}\text { Avoidance of waiting times by engaging all } \\
\text { children in a variety of activities }\end{array}$ \\
\hline High Practice Time & $\begin{array}{l}\text { Children need to have sufficient practice time to } \\
\text { engage in motor learning via trial and error }\end{array}$ \\
\hline Group Work & $\begin{array}{l}\text { Working in groups or with a partner allows } \\
\text { children to support each other in the learning } \\
\text { process }\end{array}$ \\
\hline
\end{tabular}

High motor competence subsequently provides the foundation for learning more specialized sport-specific skills [42], which increases children's motivation for a continued engagement in various sports during adolescence and into adulthood $[76,83]$. Lower competence, on the other hand, is likely associated with increased frustration due to limited success in sports participation during childhood and adolescence and contributes to a vicious cycle of limited participation in sports and PA, low motor competence and increased risk for overweight and obesity [93]. In addition to the beneficial association between motor competence, PA and body weight, there is evidence on positive associations with physical fitness and academic performance [44, 56, 61, $63,80,94-101]$, which may be an additional argument for an implementation of motor competence into physical education curricula.

\section{Summary and Conclusion}

Overall, the development of motor competence is a crucial contributor to optimal physical development and health [44, 102]. Most likely there exists a bi-directional, synergistic association between motor competence and PA as well as body weight. Youth with a better motor competence are more likely to sustain a higher level of PA, which is associated with lower body weight. Low motor competence, on the other hand, impairs engagement in sports or general PA and potentially contributes to further weight gain [58, 98, 103]. Given the inverse association of motor competence with body weight and the direct association with PA, the promotion of motor competence should be considered a viable option in the fight against insufficient PA and excess body weight in youth [59, $63,98,104]$. The reciprocal relationship between body weight and motor competence further emphasizes the need for an early intervention in order to prevent a vicious cycle of low motor competence, excess body weight and low PA [105]. Addressing poor motor competence and low PA levels at early ages is also crucial as attitudes and habits regarding PA are developed primarily during the adolescent years [106]. Despite the fact that elementary school years have been shown to be of particular importance for the development of motor abilities [107], available research indicates beneficial effects of improved motor competence on body weight in adolescents as well. Given the limited success of previous intervention strategies to improve PA in overweight and obese youth along with the well-documented benefits of motor competence on various health-related parameters, motor competence appears to be a viable intervention strategy to promote sustainable behavioral changes that facilitate an active and healthy lifestyle. Given that high motor competence is an important step towards the establishment of a lifelong commitment to PA $[57,63,68,76]$, such strategies should not only target children and adolescents but could also be of importance in adults.

\section{Conflict of Interest}

No external funding was used for this project. The author has no conflict of interest that is directly relevant to the content of this review.

\section{References}

1. Reilly JJ, Methven E, McDowell ZC, Hacking B, Alexander D, et al. 2003. Health consequences of obesity. Arch Dis Child 88(9): 748-752. doi: https://dx.doi.org/10.1136/adc.88.9.748 
2. Lobstein T, Baur L, Uauy R, IASO Intenational Obesity TaskForce. 2004. Obesity in children and young people: a crisis in public health. Obes Rev 5 Suppl 1: 4-104. doi: https://dx.doi.org/10.1111/j.1467789X.2004.00133.x

3. Bell LM, Curran JA, Byrne S, Roby H, Suriano K, et al. 2011. High incidence of obesity co-morbidities in young children: a cross-sectional study. J Paediatr Child Health 47(12): 911-917. doi: https://dx.doi. org/10.1111/j.1440-1754.2011.02102.x

4. Ng M, Fleming T, Robinson M, Thomson B, Graetz N, et al. 2014 Global, regional, and national prevalence of overweight and obesity in children and adults during 1980-2013: a systematic analysis for the Global Burden of Disease Study 2013. Lancet 384(9945): 766-781. doi: https://dx.doi.org/10.1016/S0140-6736(14)60460-8

5. Park MH, Falconer C, Viner RM, Kinra S. 2012. The impact of childhood obesity on morbidity and mortality in adulthood: a systematic review. Obes Rev 13(11): 985-1000. doi: https://dx.doi. org/10.1111/j.1467-789X.2012.01015.x

6. Thompson D, Brown J, Nichols G, Elmer P, Oster G. 2001. Body Mass Index and future healthcare costs: a retrospective cohort study. Obes Res 9(3): 210-218. doi: https://dx.doi.org/10.1038/oby.2001.23

7. Sturm R. 2002. The effects of obesity, smoking, and drinking on medical problems and costs. Health Aff (Millwood) 21(2): 245-253. doi: https:// dx.doi.org/10.1377/hlthaff.21.2.245

8. Finkelstein EA, Trogdon JG, Cohen JW, Dietz W. 2009. Annual medical spending attributable to obesity: payer-and service-specific estimates. Health Aff (Millwood) 28(5): w822-w831. doi: https://dx.doi. org/10.1377/hlthaff.28.5.w822.

9. Wang Y, Lobstein T. 2006. Worldwide trends in childhood overweight and obesity. Int J Pediatr Obes 1(1): 11-25.

10. Finkelstein EA, Khavjou OA, Thompson H, Trogdon JG, Pan L, et al. 2012. Obesity and severe obesity forecasts through 2030. Am J Prev Med 42(6): 563-570. doi: https://dx.doi.org/10.1016/j.amepre.2011.10.026

11. Sinha R, Fisch G, Teague B, Tamborlane WV, Banyas B, et al. 2002. Prevalence of impaired glucose tolerance among children and adolescents with marked obesity. $N$ Engl J Med 346(11): 802-810. doi: https://dx.doi.org/10.1056/NEJMoa012578

12. Singh AS, Mulder C, Twisk JW, van Mechelen W, Chinapaw MJ. 2008. Tracking of childhood overweight into adulthood: a systematic review of the literature. Obes Rev 9(5): 474-488. doi: https://dx.doi. org/10.1111/j.1467-789X.2008.00475.x

13. Must A. 1996. Morbidity and mortality associated with elevated body weight in children and adolescents. Am J Clin Nutr 63(3 Suppl): 445S-447S.

14. World Health Organisation. 2015. Health topics - Noncommunicable diseases - Obesity.

15. NCD-Risk Factor Collaboration. 2016. Trends in adult body-mass index in 200 countries from 1975 to 2014: a pooled analysis of 1698 population-based measurement studies with $19 \cdot 2$ million participants. Lancet 387(10026): 1377-1396. doi: https://dx.doi.org/10.1016/S01406736(16)30054-X

16. Lobstein T, Jackson-Leach R, Moodie ML, Hall KD, Gortmaker SL, et al. 2015. Child and adolescent obesity: part of a bigger picture. Lancet 385(9986): 2510-2520. doi: https://dx.doi.org/10.1016/S01406736(14)61746-3

17. Hankinson AL, Daviglus ML, Bouchard C, Carnethon M, Lewis $\mathrm{CE}$, et al. 2010. Maintaining a high physical activity level over 20 years and weight gain. JAMA 304(23): 2603-2610. doi: https://dx.doi. org/10.1001/jama.2010.1843

18. Leskinen T, Kujala UM. 2015. Health-related findings among twin pairs discordant for leisure-time physical activity for 32 years: the twinactive study synopsis. Twin Res Hum Genet 18(3): 266-272. doi: https://dx.doi.org/10.1017/thg.2015.23

19. Mozaffarian D, Ludwig DS. 2015. The 2015 US dietary guidelines: lifting the ban on total dietary fat. JAMA 313(24): 2421-2422. doi: https://dx.doi.org/10.1001/jama.2015.5941

20. Pigeot I, Baranowski T, Lytle L, Ahrens W. 2016. [Prevention of overweight and obesity in children and adolescents: critical appraisal of the evidence base]. Bundesgesundheitsblatt Gesundheitsforscbung Gesundheitsschutz 59(11): 1423-1431. doi: https://doi.org/10.1007/ s00103-016-2449-x

21. Vanderhout SM, Birken CS, Parkin PC, Lebovic G, Chen Y, et al. 2016. Relation between milk-fat percentage, vitamin $\mathrm{D}$, and BMI $\mathrm{z}$ score in early childhood. Am J Clin Nutr 104(6): 1657-1664. doi: https://dx.doi. org/10.3945/ajen.116.139675

22. Berge JM, Wall M, Hsueh TF, Fulkerson JA, Larson N, et al. 2015. The protective role of family meals for youth obesity: 10-year longitudinal associations. J Pediatr 166(2): 296-301. doi: https://dx.doi. org/10.1016/j.jpeds.2014.08.030

23. Herouvi D, Karanasios E, Karayianni C, Karavanaki K. 2013. Cardiovascular disease in childhood: the role of obesity. Eur J Pediatr 172(6): 721-732. doi: https://dx.doi.org/10.1007/s00431-013-1932-8

24. Church TS, Thomas DM, Tudor-Locke C, Katzmarzyk PT, Earnest CP, et al. 2011. Trends over 5 decades in U.S. occupation-related physical activity and their associations with obesity. PLoS One 6(5): e19657. doi: https://dx.doi.org/10.1371/journal.pone.0019657

25. Archer E, Shook RP, Thomas DM, Church TS, Katzmarzyk PT, et al. 2013. 45-Year trends in women's use of time and household management energy expenditure. PLoS One 8(2): e56620. doi: https:// dx.doi.org/10.1371/journal.pone.0056620

26. Dollman J, Norton K, Norton L. 2005. Evidence for secular trends in children's physical activity behaviour. BrJ Sports Med 39(12): 892-897.

27. Hallal PC, Andersen LB, Bull FC, Guthold R, Haskell W, et al. 2012. Global physical activity levels: surveillance progress, pitfalls, and prospects. Lancet 380(9838): 247-257. doi: https://dx.doi.org/10.1016/ S0140-6736(12)60646-1

28. Verloigne M, Van Lippevelde W, Maes L, Yıldırım M, Chinapaw M, et al. 2012. Levels of physical activity and sedentary time among 10- to 12-year-old boys and girls across 5 European countries using accelerometers: an observational study within the ENERGY-project. Int J Behav Nutr Phys Act 9: 34. doi: https://dx.doi.org/10.1186/14795868-9-34

29. Currie C, Zanotti C, Morgan A, Currie D, de Looze M, et al. 2012. Social determinants of health and well-being among young people. Health behavior in school-aged children (HBSC) study: International report from the 2009/2010 survey. WHO Regional Office for Europe, Copenhagen, Denmark.

30. Bar-Or O, Foreyt J, Bouchard C, Brownell KD, Dietz WH, et al. 1998. Physical activity, genetic, and nutritional considerations in childhood weight management. Med Sci Sports Exerc 30(1): 2-10.

31. Hallal PC, Victora CG, Azevedo MR, Wells JC. 2006. Adolescent physical activity and health: a systematic review. Sports Med 36(12): 1019-1030.

32. Must A, Tybor DJ. 2005. Physical activity and sedentary behavior: a review of longitudinal studies of weight and adiposity in youth. Int $J$ Obes (Lond) 29(Suppl 2): S84-S96.

33. Robinson LE, Stodden DF, Barnett LM, Lopes VP, Logan SW, et al. 2015. Motor competence and its effect on positive developmental trajectories of health. Sports Med 45(9): 1273-1284. doi: https://dx.doi. org/10.1007/s40279-015-0351-6

34. Metcalf B, Henley W, Wilkin T. 2012. Effectiveness of intervention on physical activity of children: systematic review and meta-analysis of controlled trials with objectively measured outcomes (EarlyBird 54). BMJ 345:e5888. doi: https://doi.org/10.1136/bmj.e5888

35. Bryant ES, Duncan MJ, Birch SL. 2014. Fundamental movement skills and weight status in British primary school children. Eur J Sport Sci 14(7): 730-736. doi: https://dx.doi.org/10.1080/17461391.2013.8702 
32

36. Lopes VP, Stodden DF, Bianchi MM, Maia JA, Rodrigues LP. 2012. Correlation between BMI and motor coordination in children.J Sci Med Sport 15(1): 38-43. doi: https://dx.doi.org/10.1016/j.jsams.2011.07.005.

37. Rodrigues LP, Stodden DF, Lopes VP. 2016. Developmental pathways of change in fitness and motor competence are related to overweight and obesity status at the end of primary school. J Sci Med Sport 19(1): 87-92. doi: https://doi.org/10.1016/j.jsams.2015.01.002

38. Cattuzzo MT, Dos Santos Henrique R, Ré AH, de Oliveira IS, Melo $\mathrm{BM}$, et al. 2016. Motor competence and health related physical fitness in youth: a systematic review. J Sci Med Sport 19(2): 123-129. doi: https://dx.doi.org/10.1016/j.jsams.2014.12.004

39. Haga M. 2008. The relationship between physical fitness and motor competence in children. Child Care Health Dev 34(3): 329-334. doi: https://dx.doi.org/10.1111/j.1365-2214.2008.00814.x

40. Vedul-Kjelsås V, Sigmundsson H, Stensdotter AK, Haga M. 2012. The relationship between motor competence, physical fitness and selfperception in children. Child Care Health Dev 38(3): 394-402. doi: https://dx.doi.org/10.1111/j.1365-2214.2011.01275.x

41. Clark J. 1994. Motor development. In Ramachandran V (ed) Encyclopedia of Human Behavior. $3^{\text {rd }}$ edn. Academic Press, New York, NY, USA. pp. 245-255.

42. Gallahue D, Ozmun J, Goodway J. 2012. Understanding Motor Development. Infants, Children, Adolescents, Adults, $7^{\text {th }}$ edn. McGrawHill, Boston, MA, USA.

43. Cliff DP, Okely AD, Smith LM, McKeen K. 2009. Relationships between fundamental movement skills and objectively measured physical activity in preschool children. Pediatr Exerc Sci 21(4): 436-449.

44. Bremer E, Cairney J. 2016. Fundamental movement skills and healthrelated outcomes: A narrative review of longitudinal and intervention studies targeting typically developping children. Am J Lifestyle Med. doi: https://dx.doi.org/10.1177/1559827616640196.

45. Cantell M, Crawford SG, Tish Doyle-Baker PK. 2008. Physical fitness and health indices in children, adolescents and adults with high or low motor competence. Hum Mov Sci 27(2): 344-362. doi: https://dx.doi. org/10.1016/j.humov.2008.02.007

46. Piek JP, Baynam GB, Barrett NC. 2006. The relationship between fine and gross motor ability, self-perceptions and self-worth in children and adolescents. Hum Mov Sci 25(1): 65-75. doi: https://doi.org/10.1016/j. humov.2005.10.011

47. Schwarz R. 2014. Frühe Bewegungserziehung [Early Movement Education]. Reinhardt, Munich, Germany.

48. Skinner RA, Piek JP. 2001. Psychosocial implications of poor motor coordination in children and adolescents. Hum Mov Sci 20(1-2): 73-94. doi: https://doi.org/10.1016/S0167-9457(01)00029-X

49. Stodden DF, Gao Z, Goodway JD, Langendorfer SJ. 2014. Dynamic relationships between motor skill competence and health-related fitness in youth. Pediatr Exerc Sci 26(3): 231-241. doi: https://dx.doi. org/10.1123/pes.2013-0027

50. Klein D, Manz K, Ferrari N, Strüder H, Graf C. 2015. Effects of health promotion projects in preschools on body mass index and motor abilities. J Sports Med Phys Fitness 55(1-2): 103-112.

51. Roth K, Ruf K, Obinger M, Mauer S, Ahnert J, et al. 2010. Is there a secular decline in motor skills in preschool children? Scand J Med Sci Sports 20(4): 670-678. doi: https://dx.doi.org/10.1111/j.16000838.2009.00982.x

52. O’Brien W, Belton S, Issartel J. 2016. Fundamental movement skill proficiency amongst adolescent youth. Phys Ed Sport Pedagogy 21(6): 557-571. doi: https://dx.doi.org/10.1080/17408989.2015.1017451

53. Hardy L, King L, Espinel P, Cosgrove C, Bauman A. 2010. NSW Schools Physical Activity and Nutrition Survey (SPANS). NSW Ministry of Health, Sydney.

54. Cliff DP, Okely AD, Morgan PJ, Jones RA, Steele JR. 2010. The impact of child and adolescent obesity treatment interventions on physical activity: a systematic review. Obes Rev 11(7): 516-530. doi: https:// dx.doi.org/10.1111/j.1467-789X.2009.00625.x

55. Cliff DP, Okely AD, Morgan PJ, Jones RA, Steele JR, et al. 2012. Proficiency deficiency: mastery of fundamental movement skills and skill components in overweight and obese children. Obesity (Silver Spring) 20(5): 1024-1033. doi: https://dx.doi.org/10.1038/oby.2011.241

56. Okely AD, Booth ML, Chey T. 2004. Relationships between body composition and fundamental movement skills among children and adolescents. Res Q Exerc Sport 75(3): 238-247. doi: https://dx.doi.org/1 0.1080/02701367.2004.10609157

57. Barnett LM, van Beurden E, Morgan PJ, Brooks LO, Beard JR. 2009. Childhood motor skill proficiency as a predictor of adolescent physical activity. J Adolesc Health 44(3): 252-259. doi: https://dx.doi. org/10.1016/j.jadohealth.2008.07.004

58. Lopes V, Maia J, Rodrigues L, Malina R. 2012. Motor coordination, physical activity and fitness as predictors of longitudinal change in adiposity during childhood. European J Sport Sci 12(4): 384-391. doi: https://dx.doi.org/10.1080/17461391.2011.566368

59. Lopes VP, Rodrigues LP, Maia JA, Malina RM. 2011. Motor coordination as predictor of physical activity in childhood. Scand J Med Sci Sports 21(5): 663-669. doi: https://dx.doi.org/10.1111/j.16000838.2009.01027.x

60. Holfelder B, Schott N. 2014. Relationship of fundamental movement skills in physical activity in children and adolescents: a systematic review. Psychol Sport Exerc 15: 382-391.doi: https://doi.org/10.1016/j. psychsport.2014.03.005

61. Hardy LL, Reinten-Reynolds T, Espinel P, Zask A, Okely AD. 2012. Prevalence and correlates of low fundamental movement skill competency in children. Pediatrics 130(2): e390-398.

62. Clark J. 2005. From the beginning: a developmental perspective on movement and mobility. Quest 57: 37-45. doi: https://dx.doi.org/10.1 080/00336297.2005.10491841

63. Logan SW, Robinson LE, Wilson AE, Lucas WA. 2012. Getting the fundamentals of movement: a meta-analysis of the effectiveness of motor skill interventions in children. Child Care Health Dev 38(3): 305315. doi: https://dx.doi.org/10.1111/j.1365-2214.2011.01307.x

64. Goodway JD, Branta CF. 2003. Influence of a motor skill intervention on fundamental motor skill development of disadvantaged preschool children. Res Q Exerc Sport 74(1): 36-46.

65. Robinson LE, Goodway JD. 2009. Instructional climates in preschool children who are at-risk. Part I: object-control skill development. Res $Q$ Exerc Sport 80(3): 533-542. doi: https://dx.doi.org/10.1080/02701367. 2009.10599591

66. Bjorklund DF, Brown RD. 1998. Physical play and cognitive development: integrating activity, cognition, and education. Child Dev 69(3): 604-606. doi: https://dx.doi.org/10.1111/j.1467-8624.1998. tb06229.x

67. Jones RA, Riethmuller A, Hesketh K, Trezise J, Batterham M, et al. 2011. Promoting fundamental movement skill development and physical activity in early childhood settings: a cluster randomized controlled trial. Pediatr Exerc Sci 23(4): 600-615. doi: https://doi. org/10.1123/pes.23.4.600

68. Morgan PJ, Barnett LM, Cliff DP, Okely AD, Scott HA, et al. 2013. Fundamental movement skill interventions in youth: a systematic review and meta-analysis. Pediatrics 132(5): e1361-e1383. doi: https:// dx.doi.org/10.1542/peds.2013-1167

69. O'Brien W, Issartel J, Belton S. 2013. Evidence for the efficacy of the youth-physical activity towards health (Y-PATH) intervention. Adv Phys Ed 3: 145-153. doi: https://dx.doi.org/10.4236/ape.2013.34024

70. Lai S, Costigan S, Morgan P, Lubans D, Stodden D, et al. 2014. Do school-based interventions focusing on physical activity, fitness, or fundamental movement skill competency produce a sustained impact in these outcomes in children and adolescents? A systematic 
review of follow-up studies. Sports Med 44(1): 67-79. doi: https://doi org/10.1007/s40279-013-0099-9

71. Zask A, Barnett LM, Rose L, Brooks LO, Molyneux M, et al. 2012. Three year follow-up of an early childhood intervention: is movement skill sustained? Int J Behav Nutr Phys Act 9: 127. doi: https://dx.doi. org/10.1186/1479-5868-9-127.

72. Logan S, Webster K, Getchell N, Pfeiffer K, Robinson L. 2015. Relationship between fundamental motor skill competence and physical activity during childhood and adolescence: a systematic review. Kinesiol Rev 4: 416-426. doi: https://doi.org/10.1123/kr.2013-0012

73. Barnett LM, Morgan PJ, Van Beurden E, Ball K, Lubans DR. 2011. A reverse pathway? Actual and perceived skill proficiency and physical activity. Med Sci Sports Exerc 43(5): 898-904. doi: https://dx.doi. org/10.1249/MSS.0b013e3181fdfadd

74. Hume C, Okely A, Bagley S, Telford A, Booth M, et al. 2008. Does weight status influence associations between children's fundamental movement skills and physical activity? Res Q Exerc Sport 79(2): 158-165.

75. Kambas A, Michalopoulou M, Fatouros IG, Christoforidis C, Manthou E, et al. 2012. The relationship between motor proficiency and pedometer-determined physical activity in young children. Pediatr Exerc Sci 24(1): 34-44. doi: https://doi.org/10.1123/pes.24.1.34

76. Stodden D, Goodway J, Langendorfer S, Roberton M, Rudisill M, et al. 2008. A developmental perspective on the role of motor skill competence in physical activity: an emergent relationshihp. Quest 60: 290-306. doi: https://dx.doi.org/10.1080/00336297.2008.10483582

77. Seefeldt V. 1980. Developmental motor patterns: Implications for elementary school physical education. In: Halliwell W, Newell K, Roberts G (eds) Psychology of motor behavior and sport. Human Kinetics, Champaign, IL, USA. pp. 314-323.

78. Williams HG, Pfeiffer KA, O’Neill JR, Dowda M, McIver KL, et al. 2008. Motor skill performance and physical activity in preschool children. Obesity (Silver Spring) 16(6): 1421-1426. doi: https://dx.doi. org/10.1038/oby.2008.214

79. Fisher A, Reilly JJ, Kelly LA, Montgomery C, Williamson A, et al. 2005. Fundamental movement skills and habitual physical activity in young children. Med Sci Sports Exerc 37(4): 684-688. doi: https://dx.doi. org/10.1249/01.MSS.0000159138.48107.7D

80. Barnett LM, Lai SK, Veldman SL, Hardy LL, Cliff DP, et al. 2016. Correlates of gross motor competence in children and adolescents: a systematic review and meta-analysis. Sports Med 46(11): 1663-1688. doi: https://doi.org/10.1007/s40279-016-0495-z

81. Harter S. 1978. Effectance motivation reconsidered: toward a developmental model. Human Development 21: 34-64. doi: https://doi. org $/ 10.1159 / 000271574$

82. Rose B, Larkin D, Berger B. 1998. The importance of motor coordination for children's motivational orientations in sport. Adapt Phys Act $Q 15$ 316-327. doi: https://doi.org/10.1123/apaq.15.4.316

83. Stodden D, Langendorfer S, Roberton MA. 2009. The association between motor skill competence and physical fitness in young adults. Res $Q$ Exerc Sport 80(2): 223-229. doi: https://dx.doi.org/10.1080/027 01367.2009 .10599556

84. D'Hondt E, Deforche B, Gentier I, De Bourdeaudhuij I, Vaeyens R, et al. 2013. A longitudinal analysis of gross motor coordination in overweight and obese children versus normal-weight peers. Int J Obes (Lond) 37(1): 61-67. doi: https://dx.doi.org/10.1038/ijo.2012.55

85. Martins D, Maia J, Seabra A, Garganta R, Lopes V, et al. 2010. Correlates of changes in BMI of children from the Azores islands. Int J Obes (Lond) 34(10): 1487-1493. doi: https://dx.doi.org/10.1038/ ijo.2010.56

86. Barnett LM, Morgan PJ, van Beurden E, Beard JR. 2008. Perceived sports competence mediates the relationship between childhood motor skill proficiency and adolescent physical activity and fitness: a longitudinal assessment. Int J Behav Nutr Phys Act 5: 40. doi: https:// dx.doi.org/10.1186/1479-5868-5-40
87. Albrecht C, Hanssen-Doose A, Oriwol D, Bös K, Worth A. 2016. Beeinflusst ein Veränderung des BMI die Entwicklung der motorischen Leistungsfähigkeit im Kindes- und Jugendalter? Ergebnisse der Motorik-Modul Studie (MoMo). Bewegungstherapie und Gesundheitssport 32: 168-172.

88. Greier K, Drenowatz C. 2017. Bi-directional association between weight status and motor competence in adolescents. (Under peerreview).

89. Riethmuller AM, Jones R, Okely AD. 2009. Efficacy of interventions to improve motor development in young children: a systematic review. Pediatrics 124(4): e782-e792. doi: https://dx.doi.org/10.1542/ peds.2009-0333

90. Wing RR, Hill JO. 2001. Successful weight loss maintenance. Annu Rev Nutr 21: 323-341. doi: https://doi.org/10.1146/annurev.nutr.21.1.323

91. Catenacci VA, Ogden LG, Stuht J, Phelan S, Wing RR, et al. 2008. Physical activity patterns in the National Weight Control Registry. Obesity (Silver Spring) 16(1): 153-161. doi: https://dx.doi.org/10.1038/ oby.2007.6

92. Branta C, Haubenstricker J, Seefeldt V. 1984. Age changes in motor skills during childhood and adolescence. Exerc Sport Sci Rev 12: 467520.

93. Graf C, Jouck S, Koch B, Staudenmaier K, von Schlenk D, et al. 2007. Motor deficits - how important are they? Monatsschr Kinderheilkd 155(7): 631-637.

94. Graf C, Koch B, Dordel S, Schindler-Marlow S, Icks A, et al. 2004. Physical activity, leisure habits and obesity in first-grade children. Eur J Cardiovasc Prev Rehabil 11(4): 284-290. doi: https://doi. org/10.1097/01.hjr.0000129740.30593.18

95. Graf C, Koch B, Kretschmann-Kandel E, Falkowski G, Christ H, et al. 2004. Correlation between BMI, leisure habits and motor abilities in childhood (CHILT-project). Int J Obes Relat Metab Disord 28(1): 2226. doi: https://dx.doi.org/10.1038/sj.ijo.0802428

96. Southall J, Okely A, Steele J. 2004. Actual and perceived physical competence in overweight and nonoverweight children. Pediatr Exerc Sci 16: 15-24. https://doi.org/10.1123/pes.16.1.15

97. Morgan PJ, Okely AD, Cliff DP, Jones RA, Baur LA. 2008. Correlates of objectively measured physical activity in obese children. Obesity (Silver Spring) 16(12): 2634-2641. doi: https://dx.doi.org/10.1038/ oby.2008.463

98. Lubans DR, Morgan PJ, Cliff DP, Barnett LM, Okely AD. 2010. Fundamental movement skills in children and adolescents: review of associated health benefits. Sports Med 40(12): 1019-1035. doi: https:// dx.doi.org/10.2165/11536850-000000000-00000

99. Hillman CH, Kamijo K, Scudder M. 2011. A review of chronic and acute physical activity participation on neuroelectric measures of brain health and cognition during childhood. Prev Med 52 (Suppl 1): S21-28. doi: https://dx.doi.org/10.1016/j.ypmed.2011.01.024

100.Jaakkola T, Hillman C, Kalaja S, Liukkonen J. 2015. The associations among fundamental movement skills, self-reported physical activity and academic performance during junior high school in Finland. $J$ Sports Sci 33(16): 1719-1729. doi: https://dx.doi.org/10.1080/026404 14.2015.1004640

101.Piek JP, Dawson L, Smith LM, Gasson N. 2008. The role of early fine and gross motor development on later motor and cognitive ability. Hum Mov Sci 27(5): 668-681. doi: https://dx.doi.org/10.1016/j. humov.2007.11.002

102.Burns RD, Brusseau TA, Fu Y, Hannon JC. 2017. Gross motor skills and cardiometabolic risk in children: a mediation analysis. Med Sci Sports Exerc 49(4): 746-751.

103.Aires L, Mendonça D, Silva G, Gaya AR, Santos MP, et al. 2010. A 3 -year longitudinal analysis of changes in Body Mass Index. Int J Sports Med 31(2): 133-137. doi: https://dx.doi.org/10.1055/s-0029-1243255

104.Barnett LM, Van Beurden E, Morgan PJ, Brooks LO, Beard JR. 2008. Does childhood motor skill proficiency predict adolescent fitness? Med 
Sci Sports Exerc 40(12): 2137-2144. doi: https://dx.doi.org/10.1249/ MSS.0b013e31818160d3

105.Pietiläinen KH, Kaprio J, Borg P, Plasqui G, Yki-Järvinen H, et al. 2008. Physical inactivity and obesity: a vicious circle. Obesity (Silver Spring) 16(2): 409-414. doi: https://dx.doi.org/10.1038/oby.2007.72

106.Malina R. 1996. Tracking of physical activity and physical fitness across the lifespan. Res Q Exerc Sport 67(3 Suppl): 48-57. doi: https://dx.doi. org/10.1080/02701367.1996.10608853

107.Malina RM, Bouchard C, Bar-Or O. 2004. Growth, maturation, and physical activity, $2^{\text {nd }}$ edn. Human Kinetics, Champaign, IL, USA.

108.Kosel A. 2010. Schulung der Bewegungskoordination: Übungen und Spiele für den Sportunterricht der Grundschule, 8 edn. Hofmann, Schorndorf, Germany. 